\title{
伝統木造建物の耐震補強法に関する研究
}

\author{
あみだ形フレームの力学特性
}

\section{STUDY ON SEISMIC REINFORCEMENT FOR TRADITIONAL WOODEN STRUCTURES}

Mechanical characteristics of Amida-shaped frame

\author{
中津 有紀子*1, 小池 哲 朗*1, 大村早 紀*2, \\ 杉野未奈*3, 高取愛子*4, 林 康 裕*5 \\ Yukiko NAKATSU, Tetsuro KOIKE, Saki OHMURA, \\ Mina SUGINO, Aiko TAKATORI and Yasuhiro HAYASHI
}

\begin{abstract}
The objective of this study is to suggest a new type of reinforcing elements, Amida-shaped frame, for traditional wooden structures. First, to make clear the mechanical characteristics of Amida-shaped frames, we conduct the static loading tests of them. Next, we analyze the difference of the restoring force characteristics and the damages between frames in parameters, size and the number of horizontal members. Finally, we simulate the static loading tests with analysis models to confirm the mechanical characteristics which can't be identified at the experiments.
\end{abstract}

Keywords: Traditional Wooden Structure, Static Loading Test, Seismic Reinforcement, Simulation Analysis, Embedment 伝統木造建物, 静的加力実験, 而震補強, シミュレーション解析, めり込み

\section{1. はじめに}

近年、1995 年兵庫県南部地震や 2007 年新潟県中越沖地震、 2016 年 熊本地震などの内陸地殼内地震によって、多くの木造建物が倒壊し ている。内陸地殸内地震に対して木造建物の倒壊を抑止するために は、適切な耐震補強を行うことが望まれる。

筆者らは、京都市域に多数現存する伝統木造住宅である京町家を

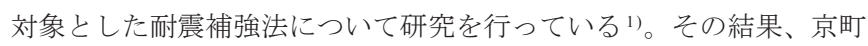
家の接合部の強度(特に、横架材の引き抜けに対する強度) は十分で なく、各階および各構面内の耐力・剛性バランスを適正にしなけれ ば、特定階への変形集中や接合部の破壊が生じ、変形性能が低下し てしまうことを実証的に示した。すなわち、合理的な耐震補強を行 うためには、補強要素の力学特性(剛性・耐力や破壊モード)を制御 可能なものとして、架構の特徴に応じて補強要素の仕様を変更可能 であることが望ましい。

伝統木造建物に対する耐震補強要素として、接合部における木材 のめり込みを利用した、面格子壁(例えぼ2) 6)やはしご型フレーム 7) 99が 提案されている。ともに耐震補強要素としては、粘り強い変形性能 を活かした補強要素である。しかし上記のような補強要素は、文献 1)の実験結果と同様に、補強場所や補強量によっては架構内での剛 性・耐力バランスが不適切となり、架構全体の変形性能を低下させ、 効果的な耐震補強とならない可能性が懸念される。
そこで本研究では、複数の間柱( 以下、柱材) とこれを繋ぐ横材で 構成される「あみだ形フレーム」を提案する。なお「あみだ形フレー ム」という名称は、「あみだくじ」に形状が似ていることから命名し た。あみだ形フレームは、面格子壁やはしご型フレームと同様に、柱 材 - 横材接合部のめり込みを利用している。しかし、あみだ形フレー ムの接合部は相欠きではなく大入れで、込栓などの栓での固定も不 要であることから製作が容易である。さらに柱材と横材の寸法・本 数・間隔などの仕様を変更することで、設計者が補強に必要とされ る耐力や変形性能から補強要素の形状を自由に決定できるため、よ り汎用性が高い。筆者らは以上の特徴を有するあみだ形フレームを 用いた補強法の構築を目指す。

本研究ではまず、あみだ形フレームの静的加力実験を実施する。 実験では大変形角まで正負交番載荷を実施し、横材の成や本数など の仕様の異なるあみだ形フレームの力学特性を把握する。そして、 実験のシミュレーション解析を実施し、実験だけでは確認できな かった、あみだ形フレームの力学特性を把握する。解析では、接合 部におけるめり込みや横材の応力・変形に影響を及ぼすと考えられ る柱材および横材に生じる軸力を考慮する。横材に生じるめり込み はもちろん、横材の曲げ変形・折損・軸力などを考慮することが、あ みだ形フレームの設計を行う上で重要であることを指摘している点 にも、本論文の独創性がある。
*1 京都大学大学院工学研究科建築学専攻 修士課程

*2 京都大学大学院工学研究科建築学専攻 博士後期課程 - 修士 (工学) (日本学術振興会特別研究員 DC1)

*3 京都大学大学院工学研究科建築学専攻 助教・博士 (工学)

*4 プリヤデザイン一級建築士事務所 博士(工学)

*5 京都大学大学院工学研究科建築学専攻 教授.工博
Grad. Student, Dept. of Architecture and Architectural Eng., Kyoto Univ. Grad. Student, Dept. of Architecture and Architectural Eng., Kyoto Univ., M.Eng. (JSPS Research Fellow, DC1)

Assist. Prof., Dept. of Architecture and Architectural Eng., Kyoto Univ., Dr.Eng. Priya Design Architect \& Associates, Dr.Eng.

Prof., Dept. of Architecture and Architectural Eng., Kyoto Univ., Dr.Eng. 


\section{2. 静的加力実験}

本章では、横材の成や本数などの仕様の異なるあみだ形フレーム の力学特性を把握するため、実大試験体の静的加力実験を実施する。

\section{1 試験体}

あみだ形フレームの横材の成や本数を実験変数とした、仕様の異 なる試験体を計 5 体製作する。Fig. 1 に試験体立面図を、Table 1 に柱材 と横材の断面寸法を示す。ここで試験体名は、「H-n - $_{2}$ - D」のように 表記する。 $\mathrm{n}_{1}, \mathrm{n}_{2}$ は横材の本数を示し、 $\mathrm{n}_{2}$ に関しては試験体の柱材が 3 本の場合のみ表記し、柱材が 2 本の試験体では表記しない。D は横 材の成 $(\mathrm{mm})$ を表す。なお、横材の幅は全ての試験体で同じ $(75 \mathrm{~mm})$ である。柱材・横材の呼称は、Fig. 1 に示す。

H-2_60、H-2_45、H-2_30 は横材の本数は同じで、成を $60 \mathrm{~mm} 、 45 \mathrm{~mm}$ 、 $30 \mathrm{~mm}$ に変えた試験体である。この 3 体の比較によって、横材の成が 試験体の水平抵抗力・横材の変形・負担できる最大曲げモーメント などに及ぼす影響を確認する。H-2_60、H-5_60、H-5-2_60は横材の寸 法は同じで、本数を変えた試験体である。H-2_60 と H-5_60 の比較に よって、試験体の水平抵抗力が横材の本数に比例するかを確認する。 さらにこの 2 体と H-5-2_60の比較によって、柱材が 2 本の試験体 2 体 の水平抵抗力の和が、柱材が 3 本の試験体 1 体の水平抵抗力となる かを確認する。

試験体を構成する柱材と横材は全て桧を使用する。柱材と横材の 接合は大入れで差し込むだけとし、差し込み深さは柱材の幅である $105 \mathrm{~mm}$ とする。Table1 に柱材と横材の材料定数を示す。密度 $\rho$ は部 材重量と部材体積から算出した值である。曲げ強度 $\mathrm{F}$ 、、横材のめり 込夕強度 $F_{m}$ は、Table1 に示寸密度 $\rho$ を文献 10)の回帰式に適用して算 出する。なお、同表の曲げヤング係数 $\mathrm{E}$ と補正係数 $\alpha$ の算出方法は 2.3 節に後述する。

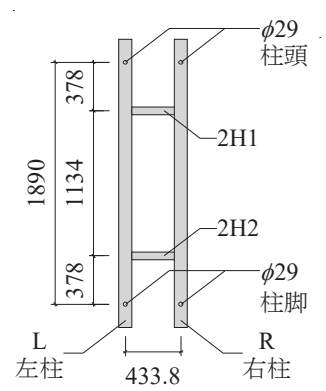

(a) $\mathrm{H}-2$ D $(\mathrm{D}=60,45,30)$

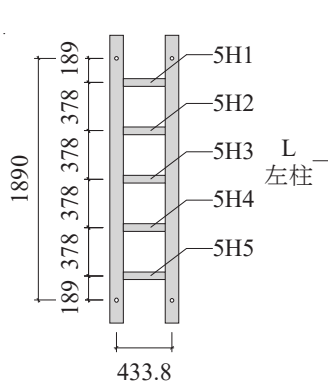

(b) $\mathrm{H}-5 \quad 60$

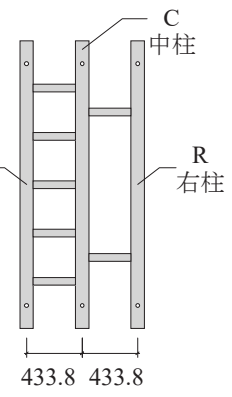

(c) $\mathrm{H}-5-2 \quad 60$
Fig.1 Elevations of specimens (Unit : $\mathrm{mm}$ ) 試験体立面図 (単位 : $\mathrm{mm}$ )

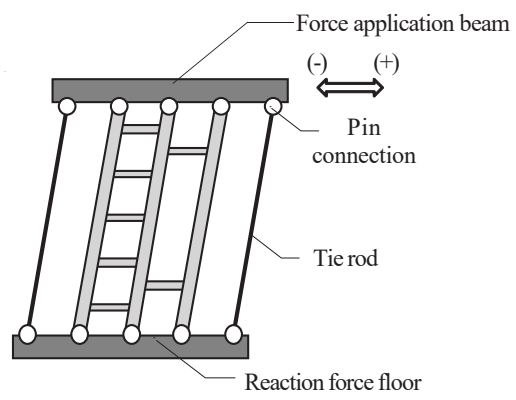

Fig.2 Loading setup 加力方法

\section{2 加力・計測方法}

Fig.2 に加力方法を示す。Fig.1 のように試験体の柱材の上部と下部 にあけた $\phi 29$ の(以下、上部の孔位置を柱頭、下部の孔位置を柱脚 と呼ぶ)にボルトを通すことで、柱頭と剛体の加力梁、柱脚と反力床 をピン接合とする。試験体両側にタイロッドを配し、加力梁と反力 床にピン接合することで、加力梁の水平を維持する。加力梁に取り 付けたアクチュエータによって、水平方向に正負交番漸増 2 回繰り返 し加力を行う。アクチュエータと加力梁の間に取り付けたロードセ ルによって得られた值から、加力梁のP $\Delta$ 効果を除いた值を試験体の 水平抵抗力 $P$ とする。加力方向は紙面右側を正側とする。

試験体の変形角 R は式(1)より算出する。

$$
\mathrm{R}=\delta / \mathrm{h}
$$

ここで $\delta$ は変位計で計測した加力梁の絶対水平変位、 $\mathrm{h}$ は柱材ピン間 距離 $(=1890 \mathrm{~mm})$ である。交番加力の目標変形角は、 $R= \pm 1 / 200 、 1 / 120$ 、 $1 / 100 、 1 / 75 、 1 / 50 、 1 / 30 、 1 / 20 、 1 / 15 、 1 / 10 、 1 / 8 、 1 / 6 、 1 / 5 \mathrm{rad}$ とする。 また、柱材・横材の同一断面上に対面させて貼付した歪㐌ージを 用いて、試験体の曲げモーメント分布を把握する。各部材の曲げ モーメントは接合部間で線形に分布すると仮定し、せん断力 Q を算 出する。曲げモーメントの算出には、Table1 の曲げヤング係数E と部 材全断面の断面係数、歪ゲージにより計測した歪を用いる。

\section{3 曲げヤング係数の補正}

歪ゲージから得られる歪と曲げヤング係数 $\mathrm{E}$ を用いて求まる層せ 几断力が水平抵抗力 $\mathrm{P}$ と一致するよう、曲げヤング係数の補正を行 う。Table1 の曲げヤング係数 E は、密度 $\rho$ を文献 10)の回帰式に適用 して算出されるE，に補正係数 $\alpha$ を乗ずることで算出する(式(2))。な お、 $\mathrm{E}$ 'を用いた場合に層せん断力と水平抵抗力 $\mathrm{P}$ が一致しない一因 として、E'を求める回帰式 ${ }^{10)}$ が試験体部材と寸法の異なる小試験体
Table1 Section size and material constants of columns and horizontal members 柱材と横材の断面寸法 - 材料定数

\begin{tabular}{|c|c|c|c|c|c|c|c|c|}
\hline Specimen & Member & Location & $\begin{array}{c}\text { Section size } \\
(\mathrm{mm})\end{array}$ & $\begin{array}{c}\rho \\
\left(\mathrm{g} / \mathrm{cm}^{3}\right)\end{array}$ & $\begin{array}{c}F_{b} \\
\left(\mathrm{~N} / \mathrm{mm}^{2}\right)\end{array}$ & $\begin{array}{c}\mathrm{F}_{\mathrm{m}} \\
\left(\mathrm{N} / \mathrm{mm}^{2}\right)\end{array}$ & $\begin{array}{c}\mathrm{E} \\
\left(\mathrm{kN} / \mathrm{mm}^{2}\right)\end{array}$ & $\alpha$ \\
\hline \multirow{4}{*}{ H-2_60 } & \multirow{2}{*}{ column } & $\overline{\bar{L}}$ & \multirow{2}{*}{$105 \times 105$} & 0.53 & 80.5 & \multirow[b]{2}{*}{-} & 8.9 & \multirow{2}{*}{0.95} \\
\hline & & $\mathrm{R}$ & & 0.56 & 83.9 & & 9.2 & \\
\hline & \multirow{2}{*}{$\begin{array}{c}\text { horizontal } \\
\text { member }\end{array}$} & $2 \mathrm{H1}$ & \multirow{2}{*}{$60 \times 75$} & 0.49 & 74.4 & 10.8 & 10.1 & \multirow{2}{*}{1.15} \\
\hline & & $2 \mathrm{H} 2$ & & 0.48 & 73.3 & 10.5 & 10.0 & \\
\hline \multirow{4}{*}{ H-2_45 } & \multirow{2}{*}{ column } & $\mathrm{L}$ & \multirow{2}{*}{$105 \times 105$} & 0.55 & 82.7 & \multirow[t]{2}{*}{ 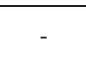 } & 12.4 & \multirow{2}{*}{1.29} \\
\hline & & $\bar{R}$ & & 0.56 & 85.0 & & 12.7 & \\
\hline & \multirow{2}{*}{$\begin{array}{c}\text { horizontal } \\
\text { member }\end{array}$} & $2 \mathrm{H1}$ & \multirow{2}{*}{$45 \times 75$} & 0.38 & 60.6 & 6.7 & 11.3 & \multirow{2}{*}{1.53} \\
\hline & & $2 \mathrm{H} 2$ & & 0.37 & 59.1 & 6.3 & 11.1 & \\
\hline \multirow{4}{*}{ H-2_30 } & \multirow{2}{*}{ column } & $\mathrm{L}$ & \multirow{2}{*}{$105 \times 105$} & 0.54 & 81.3 & \multirow{2}{*}{ - } & 12.1 & \multirow{2}{*}{1.28} \\
\hline & & $\mathrm{R}$ & & 0.58 & 87.3 & & 12.9 & \\
\hline & \multirow{2}{*}{$\begin{array}{c}\text { horizontal } \\
\text { member }\end{array}$} & $2 \mathrm{H1}$ & \multirow{2}{*}{$30 \times 75$} & 0.49 & 75.6 & 11.2 & 14.9 & \multirow{2}{*}{1.68} \\
\hline & & $2 \mathrm{H} 2$ & & 0.49 & 75.6 & 11.2 & 14.9 & \\
\hline \multirow{7}{*}{ H-5_60 } & \multirow{2}{*}{ column } & $\mathrm{L}$ & \multirow{2}{*}{$105 \times 105$} & 0.51 & 77.9 & \multirow[b]{2}{*}{-} & 12.3 & \multirow{2}{*}{1.35} \\
\hline & & $\mathrm{R}$ & & 0.50 & 76.7 & & 12.1 & \\
\hline & \multirow{5}{*}{$\begin{array}{c}\text { horizontal } \\
\text { member }\end{array}$} & $5 \mathrm{H} 1$ & & 0.52 & 78.9 & 12.2 & 15.8 & \\
\hline & & $5 \mathrm{H} 2$ & & 0.54 & 82.3 & 13.2 & 16.4 & \\
\hline & & $5 \mathrm{H} 3$ & $60 \times 75$ & 0.52 & 78.9 & 12.2 & 15.8 & 1.71 \\
\hline & & $5 \mathrm{H} 4$ & & 0.54 & 82.3 & 13.2 & 16.4 & \\
\hline & & $5 \mathrm{H} 5$ & & 0.50 & 76.7 & 11.5 & 15.4 & \\
\hline & & $\mathrm{L}$ & & 0.45 & 69.5 & & 11.3 & \\
\hline & column & $\mathrm{C}$ & $105 \times 105$ & 0.47 & 72.3 & - & 11.6 & 1.36 \\
\hline & & $\mathrm{R}$ & & 0.46 & 70.6 & & 11.4 & \\
\hline & & $5 \mathrm{H} 1$ & & 0.52 & 78.9 & 12.2 & 11.0 & \\
\hline & & $5 \mathrm{H} 2$ & & 0.53 & 80.1 & 12.5 & 11.1 & \\
\hline$\left|\mathrm{H}-5-2 \_60\right|$ & & $5 \mathrm{H} 3$ & & 0.49 & 74.4 & 10.8 & 10.4 & \\
\hline & horizontal & $5 \mathrm{H} 4$ & $60 \times 75$ & 0.50 & 76.7 & 11.5 & 10.7 & 1.19 \\
\hline & & $5 \mathrm{H} 5$ & & 0.57 & 85.7 & 14.2 & 11.8 & \\
\hline & & $2 \mathrm{H} 1$ & & 0.52 & 78.9 & 12.2 & 11.0 & \\
\hline & & $2 \mathrm{H} 2$ & & 0.48 & 73.3 & 10.5 & 10.3 & \\
\hline
\end{tabular}


(断面の辺長 $25 \mathrm{~mm}$ ) の曲げ試験結果から得られたものであることが考 えられる。

以下に補正係数 $\alpha$ の算出方法を示寸。補正係数 $\alpha$ は、式(3)〜(5)に よって算出する。Fig.3 に柱材・横材のせん断力と層せん断力の算出 方法を示す。ここで $\mathrm{h}$ は柱材のピン間距離 $(=1890 \mathrm{~mm}) 、$ I は柱材の材 芯間距離 $(=433.8 \mathrm{~mm})$ である。補正係数 $\alpha$ は柱材の曲げモーメントか ら得られる層せん断力 $\mathrm{P}_{\mathrm{c}}(\mathrm{Fig} .3)$ あるいは、横材の曲げモーメントから 得られる層せん断力 $\mathrm{P}_{\mathrm{h}}(\mathrm{Fig} .3)$ と $\mathrm{P}$ の比として、式(3)により算出する。 ここで $\mathrm{P}_{\mathrm{c}}$ は式(4)、 $\mathrm{P}_{\mathrm{h}}$ は式(5)より算出する。式中の $\mathrm{Q}_{\mathrm{ci}} 、 \mathrm{Q}_{\mathrm{hi}}$ は $\mathrm{E}^{\prime}$ を 用いて算出した、試験体の変形角 $\mathrm{R}=1 / 50 \mathrm{rad}$ 時の柱材のせん断力と横 材のせん断力である。

$$
\begin{aligned}
& \mathrm{E}=\alpha \cdot \mathrm{E}^{\prime} \\
& \alpha=\frac{\mathrm{P}}{\mathrm{P}_{\mathrm{c}}}, \frac{\mathrm{P}}{\mathrm{P}_{\mathrm{h}}} \\
& \mathrm{P}_{\mathrm{c}}=\sum_{\mathrm{i}} \mathrm{Q}_{\mathrm{ci}}\left(\mathrm{E}^{\prime}\right)
\end{aligned}
$$

$$
\mathrm{P}_{\mathrm{h}}=\sum_{\mathrm{i}} \mathrm{Q}_{\mathrm{hi}}\left(\mathrm{E}^{\prime}\right) \cdot \frac{\mathrm{l}}{\mathrm{h}}
$$

\section{4 実験結果}

\section{4 .1 損傷状況と復元力特性}

主な損傷をPhoto1 に示す。Fig.4 に、各試験体の復元力特性を示す。

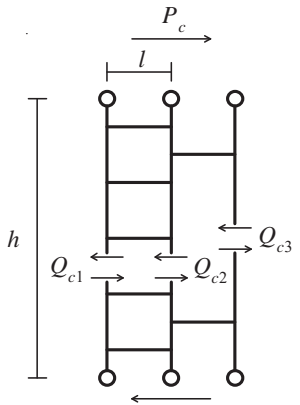

(a) Columns

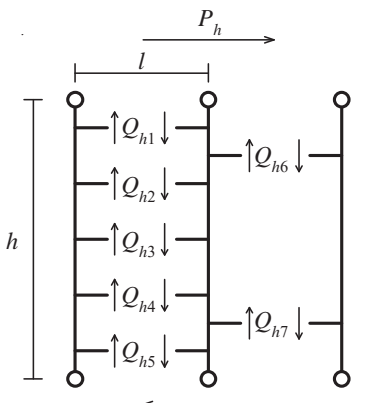

(b) Horizontal members
Fig.3 Method of calculating shearing force and story shearing force of columns and horizontal members

柱材・横材のせん断カと層せん断力の算出方法

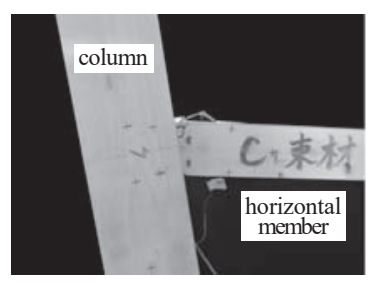

(a) Joint of column and horizontal member 柱材 - 横材接合部 (H-2_60, 2H2, R=-1/5rad)

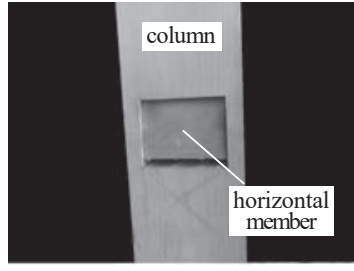

(b) Embedment of horizontal member 横材のめり込み ( $\left.\mathrm{H}-2 \_60,2 \mathrm{H} 2, \mathrm{R}=-1 / 8 \mathrm{rad}\right)$

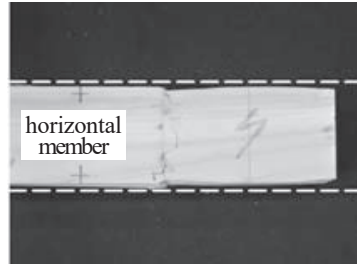

(c) Residual deformation of horizontal member 横材の残留変形

(H-5-2_60, 5H2)

Photo1 Main damages 主な損傷

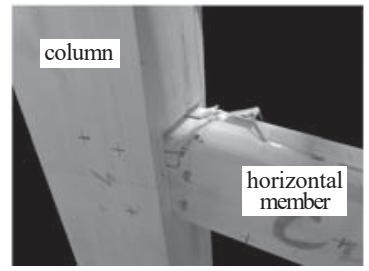

(d) Breakage of horizontal member 横材の折損

$\left(\mathrm{H}-2 \_60,2 \mathrm{H} 2, \mathrm{R}=-1 / 5 \mathrm{rad}\right)$

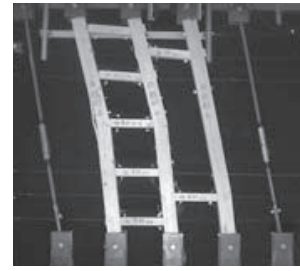

(e) Breakage of columns 柱材の折損 (H-5-2_60, R=-1/5rad)

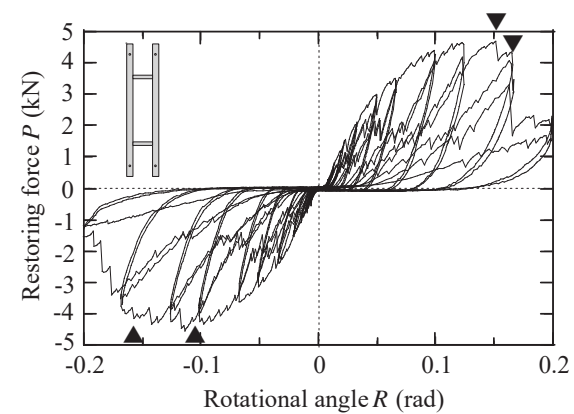

(a) $\mathrm{H}-2 \quad 60$

$(\boldsymbol{\nabla} \cdot \boldsymbol{\Delta}$ : Breakage of horizontal members)

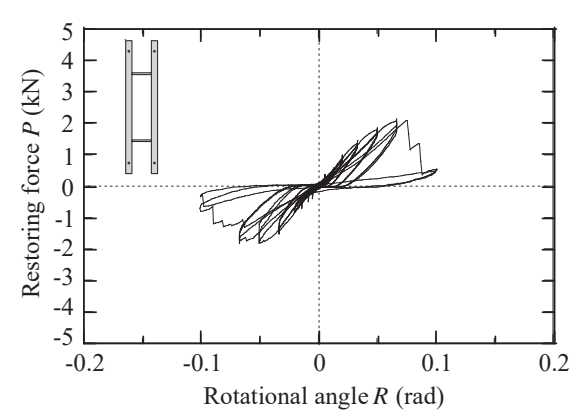

(d) $\mathrm{H}-2$

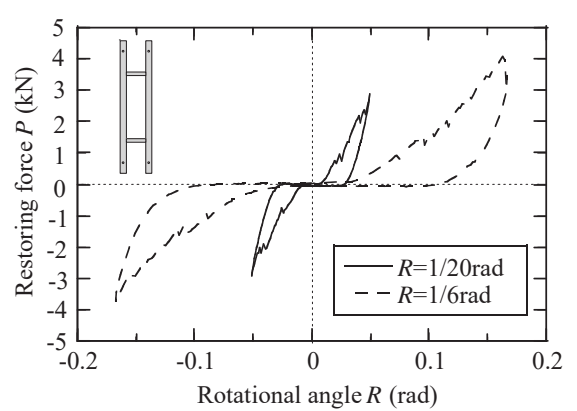

(b) $\mathrm{H}-2 \quad 60$

(Second loop of $\mathrm{R}=1 / 20,1 / 6 \mathrm{rad}$ )

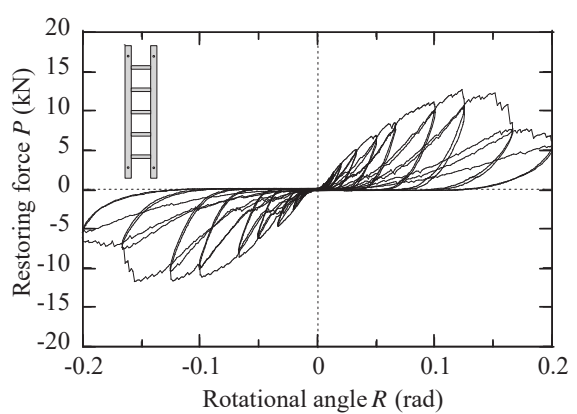

(e) $\mathrm{H}-5$-60

Fig.4 Restoring force characteristics 復元力特性

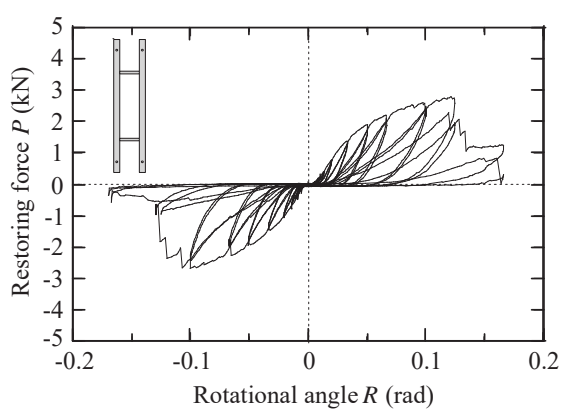

(c) $\mathrm{H}-2 \_45$

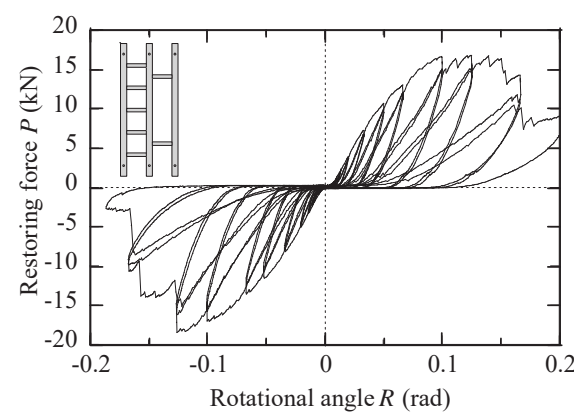

(f) $\mathrm{H}-5-2 \_60$ 
なお、Fig.4(b)ではH-2_60 の R=1/20,1/6rad 加力時の 2 ループ目の履歴を 示す。本論文では、水平抵抗力 $\mathrm{P}$ の絶対值の最大值を、最大水平抵 抗力 $\mathrm{P}_{\text {max }}$ とする。また、横材の柱材の内側表面位置において、曲げ モーメントが急激に低下した時点で生じた引張側となる面でのひび 割れを、横材の折損と定義する。

加力時の柱材 - 横材接合部をPhoto1(a)に示す。いずれの試験体で も、まず柱材 - 横材接合部で横材にめり込みが生じた(Photo1(b), (c)) が、横材の成が大きくなる程、めり込み変形は大きくなった。その 後、反対方向の加力時に、めり込みが生じた位置に引張応力が生じ ることで横材に折損が生じ(Photo1(d))、Fig.4(a)に示すように水平抵抗 力 $\mathrm{P}$ が急激に低下した。なお図中の $\boldsymbol{\nabla} \cdot \boldsymbol{\Delta}$ は、各横材の折損が正負 それぞれで最初に確認された時点を示す。横材の折損は他のす心゙て の試験体でも同様に確認された。また、めり込みの残留変形が接合 部に生じることで(Photo1(c))、変形角 R が大きくなるにつれ、水平抵 抗力 $\mathrm{P}$ が生じ始める変形角が大きくなった(Fig.4(b))。

H-5-2_60では、R=1/5rad で左柱の、R=-1/5rad で中柱と右柱のひび割 れが接合部位置で確認された(Photo(e))。

\section{4 .2 試験体間での比較}

\section{(a) 水平抵抗力}

Fig.5 に、横材の成が異なる H-2_D ( $D=60,45,30)$ の復元力特性の比 較を示す。なお、同図は正側加力時を示している。横材の成が大き くなると、横材の折損が最初に生じる変形角は増大した。この原因 の考察は 2.4.2 項 $(\mathrm{d})$ に後述する。また、横材の成が大きくなると $\mathrm{P}_{\text {max }}$ は増大した。

Fig.6に、横材の本数が異なる H-2_60、H-5_60、H-5-2_60 の復元力 特性の比較を示寸。なお、同図は正側加力時を示している。図中の 凡例「H-2_60+H-5_60」は、H-2_60 と H-5_60 の水平抵抗力 P を足し合 わせた值である。 $\mathrm{P}_{\text {max }}$ は横材の本数に概社比例した。また「H-2_60+H5_60」と H-5-2_60 の復元力特性が概水一致したことから、柱材が 2 本の試験体 2 体の水平抵抗力の和は、横材の配置が同様である柱材 が 3 本の試験体 1 体の水平抵抗力となることが確認された。

(b) 曲げモーメント分布

Fig.7 に、H-2_D ( $D=60,45,30)$ の R=1/20rad における曲げモーメント

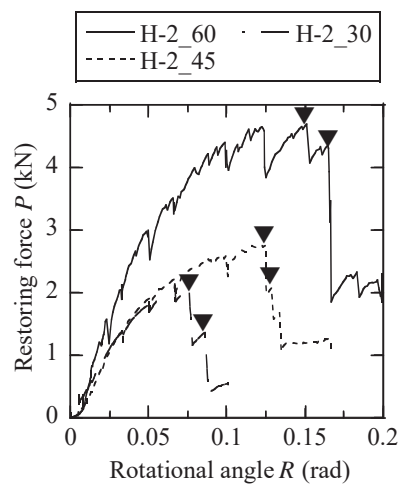

Fig.5 Restoring forces of different specimens in the size of horizontal members $(\boldsymbol{\nabla}$ : Breakage of horizontal members) 横材の成が異なる 試験体の復元力特性
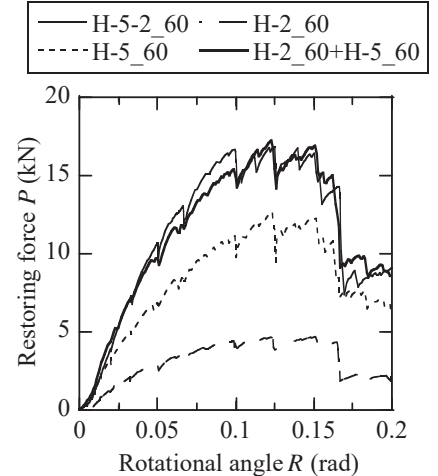

Fig.6 Restoring forces of different specimens in the number of horizontal members

横材の本数が異なる 試験体の復元力特性

分布を示す。柱材に生じる曲げモーメントの反曲点が、柱材の接合 部間の中央から上下にずれることが確認された。この原因に関する 検討は 3 章で行う。

\section{(c) 横材の変形}

Fig.8に、H-2_D ( $D=60,45,30)$ の $\mathrm{R}=1 / 20 \mathrm{rad}$ における、横材 2H1(Fig.1 参 照)の全体の変形量 $\Delta_{\mathrm{T}}$ に占める曲代変形量 $\Delta_{\mathrm{b}}$ の割合 $\Delta_{\mathrm{b}} / \Delta_{\mathrm{T}}$ を示す。変 形角 R における $\Delta_{\mathrm{T}} 、 \Delta_{\mathrm{b}}$ をそれぞれ式(6)、(7)から算出する。

$$
\begin{aligned}
& \Delta_{\mathrm{T}}=\mathrm{L} \sin \mathrm{R} \\
& \Delta_{\mathrm{b}}=\frac{\mathrm{M}_{\mathrm{av}}(\mathrm{L} \cos \mathrm{R})^{2}}{6 \mathrm{EI}}
\end{aligned}
$$

ここで L は柱材の内法間距離(328.8mm)、। は横材全断面の断面 2 次 モーメントである。EはTable1 の值を用いる。横材を柱材の内法間で 両端固定の線材と考え、横材の左右の柱材の内側表面位置には、両 位置の曲げモーメントの平均值 $M_{\mathrm{av}}$ が等しく作用するとする。Fig.8 か ら、横材の成が小さくなると、横材に生じる曲げ変形の割合が大き くなることが確認された。なお、このことは横材 $2 \mathrm{H} 2$ においても同 様に確認された。

\section{(d) 横材の最大曲げモーメント}

Fig.9 に、柱材の内側表面位置における横材の曲げモーメントの最 大值 $M_{\text {max }}$ と、曲げ強度 $F_{b}$ と断面係数 Zから得られる曲げ耐力 $F_{b} Z$ との 比較を示す。ここでZ は横材の全断面の断面係数である。横材の成 によらず、 $M_{\text {max }}$ の $F_{b} Z$ に対する比は 1.0 より小さくなる傾向が確認さ

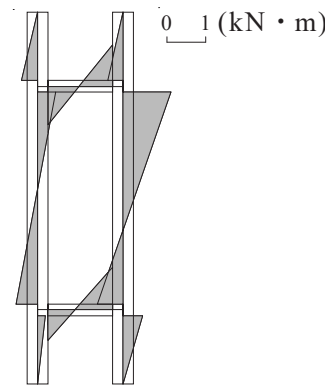

(a) $\mathrm{H}-2 \_60$

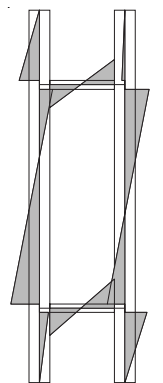

(b) $\mathrm{H}-2 \quad 45$

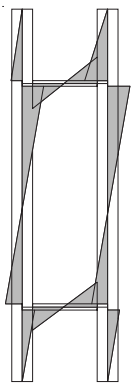

(c) $\mathrm{H}-2 \quad 30$

Fig.7 Bending moment distributions $(R=1 / 20 \mathrm{rad})$ 曲げモーメント分布

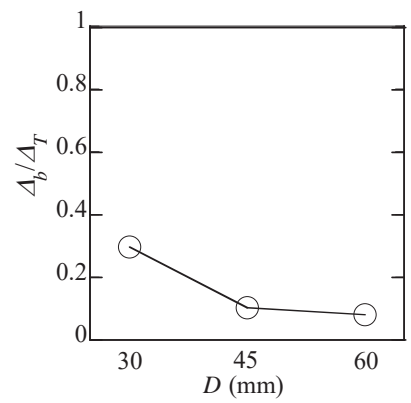

Fig.8 Ratio of $\Delta_{b}$ to $\Delta_{T}$ ( $\left.\mathrm{H}-2 \_D, 2 \mathrm{H} 1, R=1 / 20 \mathrm{rad}\right)$ $\Delta_{T}$ に占める $\Delta_{b}$ の割合

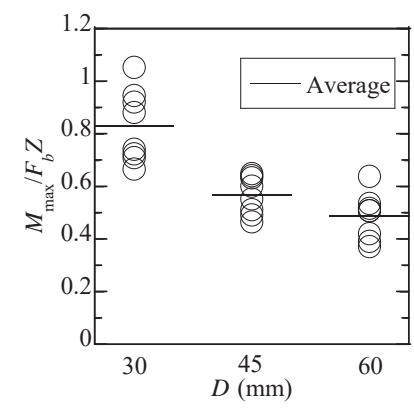

Fig.9 Comparison of $M_{\max }$ with $F_{b} Z$ $\left(\mathrm{H}-2 \_D\right)$ $M_{\max }$ と $F_{b} \bar{Z}$ の比較 
れた。さらに、横材の成が大きくなると、 $M_{\text {max }}$ の $F_{b} Z$ に対する比は低 下した。上記の原因として、以下のことが考えられる。まず、 $M_{\text {max }}$ の $\mathrm{F}_{b} \mathrm{Z}$ に対する比が 1.0 より小さくなる傾向に関して述べる。本論文の 静的加力実験では、大变形角まで正負交番載荷を実施している。そ のため、柱材が横材にめり込むことによって、横材の柱材の内側表 面位置の繊維が切られ、反対方向の変形角で繊維が切られた位置に 引張応力が作用することが一因と考えられる。次に、横材の成が大 きくなると $M_{\text {max }}$ の $F_{b} Z$ に対する割合が低下した一因として、横材の成 が大きくなると、Fig. 8 に示寸通り接合部における曲げ変形の割合が 小さく、すなわちめり込み变形が卓越し、柱材が横材にめり込むこ とによってより横材の繊維が切られたことが考えられる。

一方、前述のように横材の成が大きくなると横材の折損が最初に 生じる変形角が増大寸る。この一因として、以下のことが考えられ る。Fig.9 に示すように、横材の成が大きくなると、横材の $M_{\text {max }}$ の $F_{b} Z$ に対する割合は低下寸るが、断面係数 $\mathrm{Z}$ の増大に伴い横材の $\mathrm{F}{ }_{b} \mathrm{Z}$ は増 大寸る。さらに、横材の成が大きくなると横材の曲げ剛性 EI が増大 し、曲げ破壞よりもめり込み降伏が先行する。この結果、横材のめ り込みによる回転変形が進展しやすくなり、加えて $\mathrm{F}_{b} \mathrm{Z}$ は増大寸るた め、横材が折損に至るまでの変形角 R が増大したと考えられる。

\section{3. シミュレーション解析}

本章では、2 章の静的加力実験のシミュレーション解析を実施し、 実験だけでは確認できなかった、あみだ形フレームの力学特性を把 握する。

\section{1 解析方針}

解析では、柱材・横材を線形の梁要素、接合部を非線形バネ不要素 で表現した平面骨組解析モデルを用いて、非線形挙動を追跡する。 解析ソフトには、任意形状立体フレームの弾塑性解析プログラム SNAP(ver.6)を用い、P $\Delta$ 効果を考慮しない静的変位増分解析を行う。

解析は 3 ケース実施する。まず部材の曲げ変形の影響を分析する ため、柱材と横材の曲げヤング係数を変えたCase 1,2 を実施する。さ らに、横材の軸力に関係するめり込み摩擦力の影響を分析するため、 Case 1 に対してめり込み摩擦力の与え方を変えた Case3 を実施する。

\section{2 解析モデル}

Fig.10 に解析モデルを、Fig.11 に正側加力時の柱材 - 横材接合部に生 じるめり込みと力の模式図を示す。なお、柱材 - 横材接合部のめり込 みは、文献 11 ) と同様に三角変位めり込みを仮定する。

\section{(a) 柱材 · 横材}

各部材の材軸上に沿って節点間に梁要素を配置することで、柱材・ 横材をモデル化する。Fig.10(a)〜(c)に示すように、柱材には、材端 と、横材の上面・下面と柱材の材軸の交点 $(\mathrm{a} 1, \mathrm{~b} 1, \mathrm{c} 1, \mathrm{~d} 1)$ に節点を設け る。横材には、Fig.11の $N_{S} 、 N_{L}$ の作用する位置である a3,b3,c3,d3 に節 点を設ける。ここで、 $N_{S} 、 N_{L}$ は柱材 - 横材接合部の横材に作用するめ り込み力の合力であり、柱材の直下部のめり込み応力分布の重心位 置に作用させる。なお、めり込み長さは差し込み深さdの $1 / 2$ 倍とす る。断面寸法、曲げヤング係数 E 、密度 $\rho$ は Table 1 の值を用いる。せ 儿断弾性係数は文献 11) に従い、E の $1 / 15$ 倍と寸る。柱材・横材の断 面積と断面 2 次モーメントは全断面で算出する。なお、柱材 - 横材接 合部 (a1-b1 間,c1-d 1 間)では、ほぞ孔による柱材の断面欠損を考慮す る。

\section{(b) 柱材 - 横材接合部}

柱材は a1,b1,c1,d1 と a2,b2,c2,d2 を、横材は a3,b3,c3,d3 と a2’, ,b2’,c2’ , $\mathrm{d} 2$ ’を、剛とみなせる梁要素でそれぞれ結ぶ。(a2, a 2 ')、(b2, b2 ’)、 (c2, c2 ')、(d2, d 2') はそれぞれ節点間の距離を微小とし(以下、2 重 節点と呼ぶ)、2 重節点間に鉛直方向バネと水平方向バネを配置する ことで、Fig.11 に示すめり込み応力分布の重心位置にバネ不要素の復元 力を作用させる。なお、接合部に配置したバネ要素の変形は、圧縮 を正とする。

以下、バネ要素の復元力特性について述べる。Fig.10(d),(e)にバネ の復元力特性を示す。鉛直方向バネは柱材 - 横材接合部におけるめり 込み力 $\mathrm{N}_{5} 、 \mathrm{~N}_{\mathrm{L}}$ を、水平方向バネはめり込み摩擦力 $\mathrm{H}_{\mathrm{S}} 、 \mathrm{H}_{\mathrm{L}}$ を表現する (Fig.11)。ここで、a2-a2'、c2-c2’ のバネにはN $\mathrm{N}_{\mathrm{L}} 、 \mathrm{H}_{\mathrm{L}}$ を、b2-b2'、d2-d2' のバネには $\mathrm{N}_{5} 、 \mathrm{H}_{\mathrm{s}}$ を与える。接合部のめり込み力における、Fig.10(d) の初期剛性 $K_{05} 、 K_{0 L}$ と降伏耐力 $N_{S y} 、 N_{L y}$ は、文献 11) と同様に算出する。 $K_{0 L 、 N_{L y}}$ の算出では、Fig.11 に示す $x_{1}$ を無限大と考える。Table2 に、各 試験体の鉛直方向バネのパラメータを示寸。なお、2 次剛性は $K_{0}$ の $1 / 6$ 倍とする ${ }^{11)}$ 。復元力特性の算出に用いる曲げヤング係数 $E$ 、めり 込夕強度 $F_{m}$ はT Table1 に示寸值を用いる。めり込み摩擦力については、 Fig.10(e)に示すように剛とみなせる初期剛性 $K_{r}\left(=10^{4} \mathrm{kN} / \mathrm{mm}\right)$ を与え、2 次剛性は $K_{r}$ の $1 / 10^{5}$ 倍とする。なお、めり込み摩擦力はめり込み力と 連成していない。

\section{(c) 柱頭 · 柱脚}

2 章の実験における加力条件を再現するため、柱頭の全ての節点の 鉛直・水平方向の変位を同一とし、回転方向は自由とする。柱脚の 節点は、鉛直・水平方向を固定し、回転方向のみ自由とする。

\section{3 解析ケース}

前述のとおり、解析は 3 ケース実施する。Table3 に各解析ケースの パラメータを示す。まず部材の曲げ変形の影響を分析するため、柱 材と横材の曲げヤング係数を変えたCase 1,2 を実施する。Case 1 では Table1 に示寸曲げヤング係数E を用いるのに対し、Case2 では曲げヤ ング係数 $\mathrm{E}_{\mathrm{r}}\left(=10^{12} \mathrm{kN} / \mathrm{mm}^{2}\right)$ を用い、柱材と横材を剛とみなす。さらに 横材の軸力に関係するめり込み摩擦力の影響を分析するため、Case 1 に対してFig.10(e)の降伏耐力 $H_{S y} 、 H_{L y}$ を変化させたCase3 を実施する。 b2-b2'、d2-d2'に与えるめり込み摩擦力の降伏耐力 $\mathrm{H}_{\mathrm{sy}}$ は、Case1,3 と もに0.4N $\mathrm{N}_{\mathrm{sy}}$ とする。a2-a2’、c2-c2'に与えるめり込み摩擦力の降伏耐 力 $\mathrm{H}_{\mathrm{Ly}}$ は、Case1 では $0.4 \mathrm{~N}_{\mathrm{Ly}} 、$ Case 3 では $0.4 \mathrm{~N}_{\mathrm{Sy}}$ とする。ここで 0.4 は文 献 12 )を参考とした静止摩擦係数である。

\section{4 解析結果}

本節では、試験体のシミュレーション解析結果を実験結果と比較 し、考察を行う。なお、解析は各試験体の実験での加力終了時の変 形角まで実施する。

\section{4 .1 復元力特性}

Fig.12 に、曲げヤング係数が異なるケースの復元力特性(Case1,2)を 示寸。Fig.13に、めり込み摩擦力が異なるケースの復元力特性(Case1,3) を示す。

Fig.12より、試験体によらず、Case1 の方が Case2 よりも初期剛性が 小さく、より実験結果に対応した結果が得られている。初期剛性の 差は、特にH-2_30 で顕著に表れており、結果としてCase1 の方が横材 折損時までの復元力特性をより適切に表現できている。

Fig.13より、復元力特性は試験体によらずCase 1,3 で大きな違いは確 
認されなかった。つまり、めり込み摩擦力を変化させても、試験体 の復元力特性には大きな変化が生じないことが確認された。

\section{4 .2 曲げモーメント分布と横材の軸力}

Fig.14に、Case1,3で得られた、H-2_60 の R=1/20radにおける曲げモー メント分布と横材に作用する軸力の比較を示す。なお、曲げモーメ ント分布内の数值は柱材内法間の横材の軸力を示しており、引張を 正、圧縮を負とする。

曲げモーメント分布について、Case1 では実験(2.4.2 項(b))で確認 された、柱材の反曲点が接合部間の中央からずれることを再現でき ている。しかし、実験結果(Fig.7(a))に比べ反曲点の中央からのずれが 大きい。また、Case3 では柱材の反曲点はおおよそ中央に位置してい る。

横材の軸力について、Case1 では横材の柱材内法間に圧縮軸力が作 用しているが、Case3 では横材に軸力はほぼ生じていない。これは横 材の軸力が、柱材 - 横材接合部におけるめり込み摩擦力 $\mathrm{H}_{\mathrm{S}}$ と $\mathrm{H}_{\mathrm{L}}$ の差 によって生じているためである。以上より、柱材の反曲点が中央か らずれる要因として、めり込み摩擦力によって生じる横材の軸力が 挙げられ、横材の軸力を考慮しなければ、柱材の曲げモーメント分
布の適切な評価が難しいことが分かる。

既往の研究では横材の軸力が考慮されているものはなく223)879)、柱 材の反曲点は接合部間の中央であると想定されている。柱材の反曲 点が中央からずれることによって、中央にあると想定する場合より も接合部に作用寸る曲げモーメントが大きくなり、柱材の折損が想 定より早期に発生するおそれがある。

\section{4. まとめ}

本論文では、伝統木造建物の耐震補強に適した補強要素「あみだ 形フレーム」を提案するため、あ夕だ形フレームの力学特性( 剛性・ 耐力や破壊モード)の把握を目的とした静的加力実験を実施した。ま た、実験結果を概ね説明可能な解析モデルを提示し、力学特性の分 析を行った。あみだ形フレームの力学特性について、得られた知見 を以下に示す。

1) あみだ形フレームの最大水平抵抗力は、横材の本数に概水比例し た。特徵的な損傷として、柱材 - 横材接合部の柱材の内側表面位 置での横材の折損が挙げられる。横材に折損が生じると水平抵抗 力が急激に低下した。

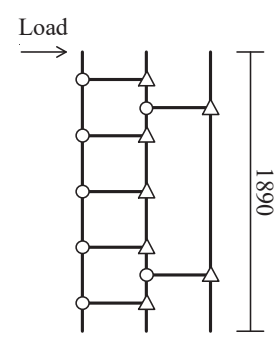

(a) Whole model(H-5-2 60) (Unit: $\mathrm{mm}$ ) モデル全体(H-5-2_60)

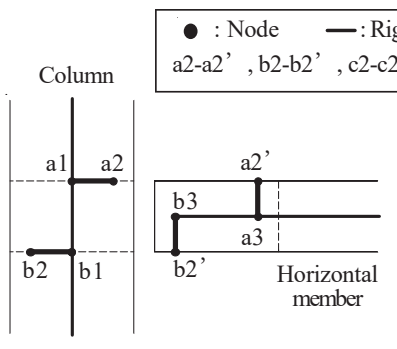

(b) Joint of column and horizontal member $(\bigcirc)$ 柱材 - 横材接合部 $(\bigcirc)$

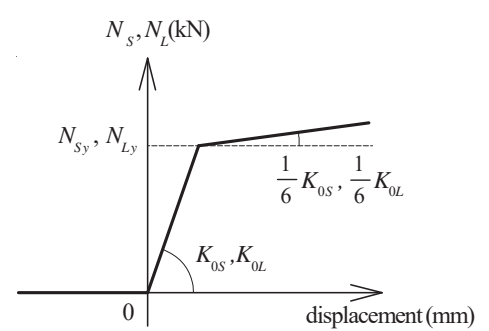

(d) Restoring force characteristic of vertical spring

鈶直方向バネの復元力特性
Fig.10 Analysis model

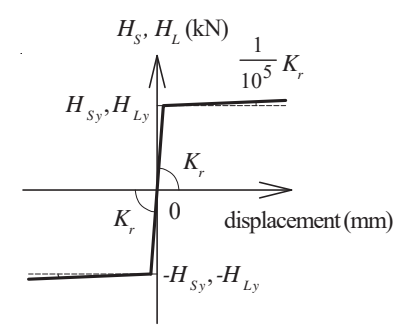

(e) Restoring force characteristic of horizontal spring 水平方向バネの復元力特性

解析モデル

(c) Joint of column and horizontal member $(\triangle)$
柱材 - 横材接合部 $(\triangle)$

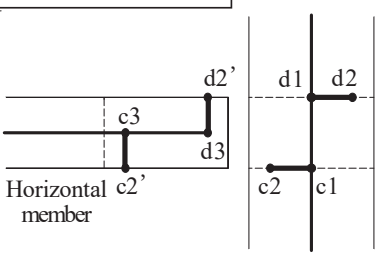

Column

$\triangle)$
Table2 Parameters of vertical springs of each specimen

各試験体の鉛直方向バネのパラメータ

\begin{tabular}{|c|c|c|c|c|c|}
\hline \multirow{2}{*}{ Specimen } & \multirow{2}{*}{ Member } & \multicolumn{2}{|c|}{ Rigidity $(\mathrm{kN} / \mathrm{mm})$} & \multicolumn{2}{|c|}{ Yield strength $(\mathrm{kN})$} \\
\hline & & $\mathrm{K}_{0 \mathrm{~S}}$ & $\mathrm{~K}_{0 \mathrm{~L}}$ & $\mathrm{~N}_{\mathrm{sy}}$ & $\mathrm{N}_{\mathrm{Ly}}$ \\
\hline \multirow{2}{*}{ H-2_60 } & $2 \mathrm{H1}$ & 9.9 & 25.3 & 9.9 & 15.7 \\
\hline & $2 \mathrm{H} 2$ & 9.8 & 25.0 & 9.6 & 15.3 \\
\hline \multirow{2}{*}{ H-2_45 } & $2 \mathrm{H1}$ & 14.8 & 32.2 & 6.8 & 9.9 \\
\hline & $2 \mathrm{H} 2$ & 14.5 & 31.5 & 6.3 & 9.3 \\
\hline \multirow{2}{*}{ H-2_30 } & $2 \mathrm{H1}$ & 29.4 & 52.4 & 12.7 & 16.9 \\
\hline & $2 \mathrm{H} 2$ & 29.4 & 52.4 & 12.7 & 16.9 \\
\hline \multirow{5}{*}{ H-5_60 } & $5 \mathrm{H1}$ & 15.5 & 39.2 & 11.1 & 17.7 \\
\hline & $5 \mathrm{H} 2$ & 16.1 & 40.6 & 12.1 & 19.1 \\
\hline & $5 \mathrm{H} 3$ & 15.5 & 39.2 & 11.1 & 17.7 \\
\hline & $5 \mathrm{H} 4$ & 16.1 & 40.6 & 12.1 & 19.1 \\
\hline & $5 \mathrm{H} 5$ & 15.2 & 38.2 & 10.5 & 16.7 \\
\hline \multirow{7}{*}{ H-5-2_60 } & $5 \mathrm{H1}$ & 10.8 & 27.3 & 11.1 & 17.7 \\
\hline & $5 \mathrm{H} 2$ & 10.9 & 27.6 & 11.4 & 18.2 \\
\hline & $5 \mathrm{H} 3$ & 10.3 & 25.9 & 9.9 & 15.7 \\
\hline & $5 \mathrm{H} 4$ & 10.5 & 26.6 & 10.5 & 16.7 \\
\hline & $5 \mathrm{H} 5$ & 11.6 & 29.3 & 13.0 & 20.6 \\
\hline & $2 \mathrm{H1}$ & 10.8 & 27.3 & 11.1 & 17.7 \\
\hline & $2 \mathrm{H} 2$ & 10.1 & 25.6 & 9.6 & 15.3 \\
\hline
\end{tabular}

Table3 Parameters of each analysis case 各解析ケースのパラメータ

\begin{tabular}{|c|c|c|c|}
\hline \multirow{2}{*}{ Case } & \multirow{2}{*}{$\begin{array}{c}\text { Young's modulus } \\
\left(\mathrm{kN} / \mathrm{mm}^{2}\right)\end{array}$} & \multicolumn{2}{|c|}{ Yield strength $(\mathrm{kN})$} \\
& & $\mathrm{H}_{\mathrm{Sy}}$ & $\mathrm{H}_{\mathrm{Ly}}$ \\
& $\mathrm{E} 2-\mathrm{b} 2 ', \mathrm{~d} 2-\mathrm{d} 2$ & $\mathrm{a} 2-\mathrm{a} 2 ', \mathrm{c} 2-\mathrm{c} 2$ \\
\hline 1 & $\mathrm{E}_{\mathrm{r}}$ & & \multirow{2}{*}{$0.4 \mathrm{~N}_{\mathrm{Sy}}$} \\
& $\mathrm{E}$ & & $0.4 \mathrm{~N}_{\mathrm{Ly}}$ \\
\hline 3 & & & $0.4 \mathrm{~N}_{\mathrm{Sy}}$ \\
\hline
\end{tabular}

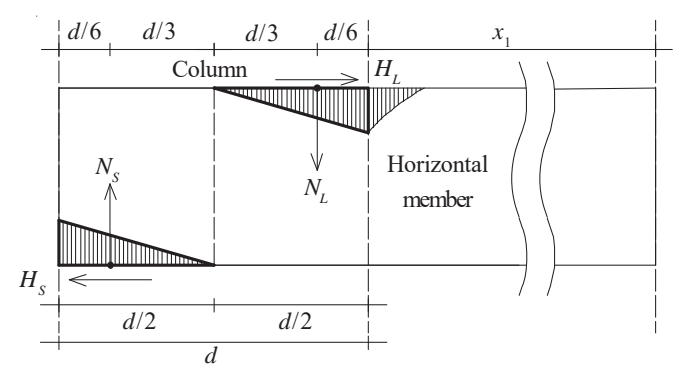

- : Center of gravity of triangle stress distribution

$\mathrm{N}_{\mathrm{s}}$ : Force by embedment(b2-b2' , d2-d2')

$\mathrm{N}$ : Force by embedment(a2-a2', , c2-c2')

$\mathrm{H}_{\mathrm{S}}$ : Friction force by embedment(b2-b2' , d2-d2')

$\mathrm{H}_{\mathrm{L}}$ : Friction force by embedment(a2-a2',, $\left.\mathrm{c} 2-\mathrm{c} 2^{\prime}\right)$

Fig.11 Pattern diagram of embedment and forces at joint of column and horizontal member ((+)direction) 柱材 - 横材接合部に生じるめり込みとカの模式図 (正側加力時) 
2) 横材の成が大きくなると、横材折損時の変形角と最大水平抵抗力 は増大した。ただし、横材の最大曲げモーメントの曲げ耐力に対 する比は、横材の成が大きいほど低下した。

3) 横材の成が小さくなると、横材の曲げ変形を考慮しなければあみ だ形フレームの初期剛性を過大評価する。

4) 柱材の曲げモーメント分布を適切に評価するためには、柱材 - 横 材接合部のめり込み摩擦力と横材の軸力を考慮する必要がある。 なお、横材の曲げやめり込みによる変形よりも柱材の曲げ変形が 卓越したり、横材の折損に先行して柱材が折損したりする場合には、 上記の知見と異なる力学特性を示寸と考えられる。ただしその場合 も、本論文で提示した解析モデルを用いて、力学特性の変化を概ね 把握可能であると考えている。

\section{謝辞}

本研究は、科学研究費補助金基盤(A)No.15H02275(代表者:林康裕 )の補助の下で遂行した。ここに記して謝意を示す。

\section{参考文献}

1) Koike, T., Ohmura, S., Sugino, M. and Hayashi, Y. : Experimental Study on Seismic Reinforcement of Traditional Town Houses in Kyoto, Journal of Structural and Construction Engineering (Transactions of AIJ), Vol.82, No.736, pp.843-852, 2017.6. (in Japanese)

小池哲朗，大村早紀，杉野未奈，林康裕：京町家の耐震補強に関する実験的 研究, 日本建築学会構造系論文集, 第82巻, 第736号, pp.843-852, 2017.6.

2) Iwasaki, T., Takemura, M., Inayama, M. and Murakami, M. : Development of Structural Design Method on Conventional Post and Beam Structures Part61 Structural Design
Concept on Timber Grille Walls, Summaries of Technical Papers of Annual Meeting, Architectural Institute of Japan, Structure III, pp.379-380, 2002.8. (in Japanese) 岩崎敏之, 竹村雅行, 稲山正弘, 村上雅英 : 在来軸組工法木造住宅の構造設計 手法の開発その61 直交面格子壁の剛性・耐力算定式,日本建築学会大会学術 講演梗概集, 構造III, pp.379-380, 2002.8.

3) Takada, T. and Nakanishi, T. : A Model of Restoring Force Characteristic for Panel Type Grid Wall Based on Lateral Loading Tests, Journal of Structural Engineering, Vol.58B, pp.251-257, 2012.3. (in Japanese)

高田豊文, 中西智也 : 水平加力試験に基づくパネル型面格子壁の復元力特性 モデルに関する考察, 構造工学論文集, 第58B巻, pp.251-257, 2012.3.

4) Kusunoki, T. and Ohno, M. : Experimental Study on Structural Performance of Wooden Grid Shear Wall Reinforced by Plywood, AIJ Journal of Technology and Design, Vol.19, No.42, pp.513-518, 2013.6. (in Japanese)

楠寿博, 大野正人 : 合板補剛木造面格子壁の構造特性に関する実験的研究, 日 本建築学会技術報告集, 第19巻, 第42号, pp.513-518, 2013.6.

5) Hiroishi, S., Okada, A., Miyasato, N., Satoh, K. and Saitoh, M. : Effect of Grid Spacing on Strength and Stiffness of Grid Wall, Journal of Structural and Construction Engineering (Transactions of AIJ), Vol.78, No.694, pp.2183-2190, 2013.12. (in Japanese) 廣石秀造, 岡田章, 宮里直也, 佐藤公紀, 斉藤公男: 木造面格子壁の格子間隔が 剛性と耐力に及ぼす影響, 日本建築学会構造系論文集, 第78巻, 第694号, pp.21832190, 2013.12.

6) Aikawa, S., Okada, A., Miyasato, N., Hiroishi, S. and Hoshino, T. : Study on Basic Structual Properties of Wooden Grid Wall Consisting of Half-Lap Joint (Part1) Energy Absorption Performance by Static Loading Tests of Half-Lap Joint and Wooden Grid Wall, Summaries of Technical Papers of Annual Meeting, Architectural Institute of Japan, Structure III, pp.327-328, 2015.9. (in Japanese)

相川翔太, 岡田章, 宮里直也, 廣石秀造, 星野達哉: 相欠き仕口を用いた木造面 格子壁の基本的構造特性に関する研究(その1)相欠き仕口・面格子壁の静的載 荷実験によるエネルギー吸収性能, 日本建築学会大会学術講演梗概集, 構造III

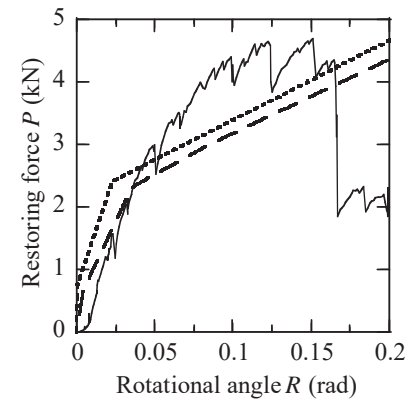

(a) $\mathrm{H}-260$

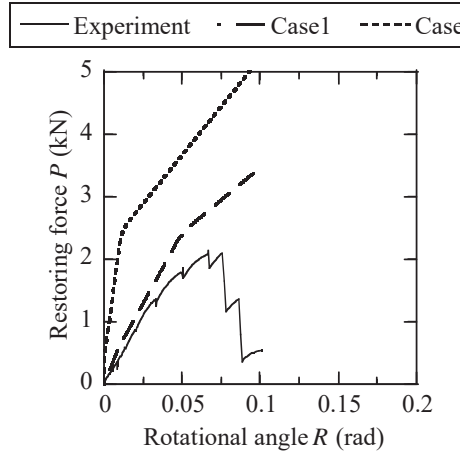

(b) $\mathrm{H}-2$

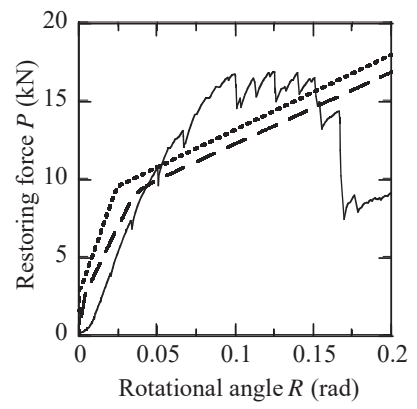

(c) $\mathrm{H}-5-2 \quad 60$ 曲げヤング係数が異なるケースの復元カ特性

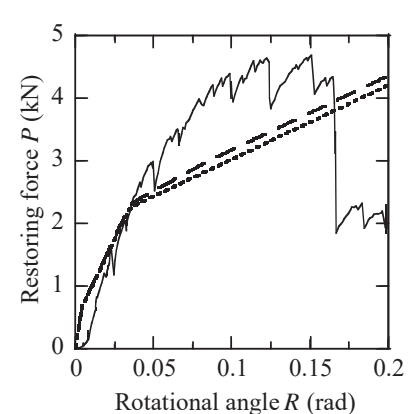

(a) $\mathrm{H}-2 \_60$

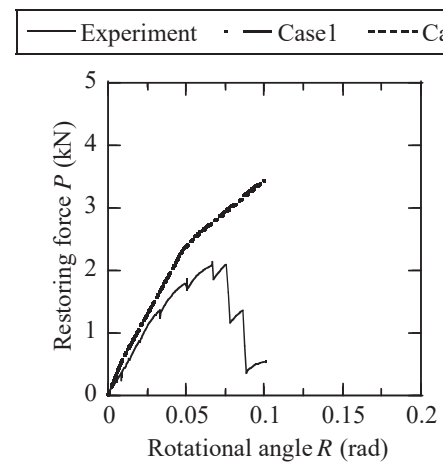

(b) $\mathrm{H}-2$ _30

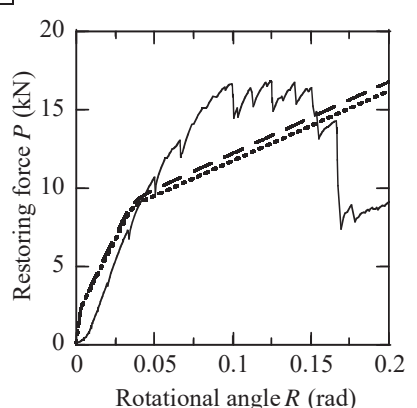

(c) $\mathrm{H}-5-2 \quad 60$

Fig.13 Restoring forces of different cases in friction force by embedment (Case1,3) めり込み摩擦力が異なるケースの復元力特性

: Axial force of horizontal member(Unit : $\mathrm{kN})$ $(+:$ tensile, - : compression)

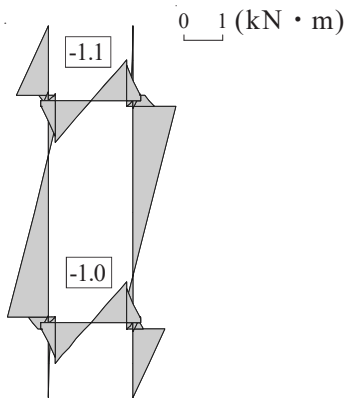

(a) Case 1

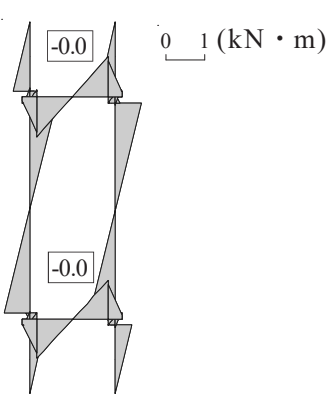

(b) Case 3

Fig.14 Comparison of bending moment distributions and axial force of horizontal members (H-2_60, R=1/20rad)

曲げモーメント分布と 横材に作用する軸力の比較 
,pp.327-328, 2015.9.

7) Okamura, M., Suzuki, Y., Suda, T. and Tanahashi, H. : Restoring Force Characteristics and Resistance Mechanism of Wooden Laddery Frames, Summaries of Technical Papers of Annual Meeting, Architectural Institute of Japan, Structure III, pp.433-434, 2007.8. (in Japanese)

岡村雅克, 鈴木祥之, 須田達, 棚橋秀光: はしご型フレームの復元力特性と抵 抗メカニズム, 日本建築学会大会学術講演梗概集, 構造III, pp.433-434, 2007.8.

8) Shirayama, A. and Suzuki, Y. : Seismic Reinforcement Effect of Laddery Beam Installed with Viscoelastic Dampers, AIJ Journal of Technology and Design, Vol.14, No.27, pp.55-59, 2008.6. (in Japanese)

白山敦子, 鈴木祥之: 減衰型粘弾性ダンパーを用いた梯子状梁による耐震補 強効果, 日本建築学会技術報告集, 第14巻, 第27号, pp.55-59, 2008.6.

9) Tanahashi, H. and Suzuki, Y.: Seismic Reinforcement of Traditional Timber Structures by Ladder-type Frames, Proc. of urban cultural heritage disaster mitigation, Vol.2,
2008.10. (in Japanese)

棚橋秀光, 鈴木祥之: はしご型フレームによる伝統木造構造物の耐震補強, 歴 史都市防災論文集, 第2巻, pp.171-178, 2008.10.

10) Nakai, T. and Yamai, R. : Properties of the Important Japanese Woods The mechanical properties of 35 important Japanese woods, Bulletin of the Forest Experiment Institute, No.319, pp.13-46, 1982.1.(in Japanese)

中井孝, 山井良三郎: 日本産主要樹種の性質日本産主要35樹種の強度的性質 , 林業試験場研究報告, 319号, pp.13-46, 1982.1.

11) Architectural Institute of Japan : Standard for Structural Design of Timber Structures, pp.305-307, 2006.12. (in Japanese)

日本建築学会 : 木質構造設計基準・同解説, pp.305-307,396, 2006.12.

12) Architectural Institute of Japan : Design Manual for Engineered Timber Joints, pp.253, 2009.11. (in Japanese)

日本建築学会 : 木質構造接合部設計マニュアル,pp.253, 2009.11. 
STUDY ON SEISMIC REINFORCEMENT FOR TRADITIONAL WOODEN STRUCTURES

Mechanical characteristics of Amida-shaped frame

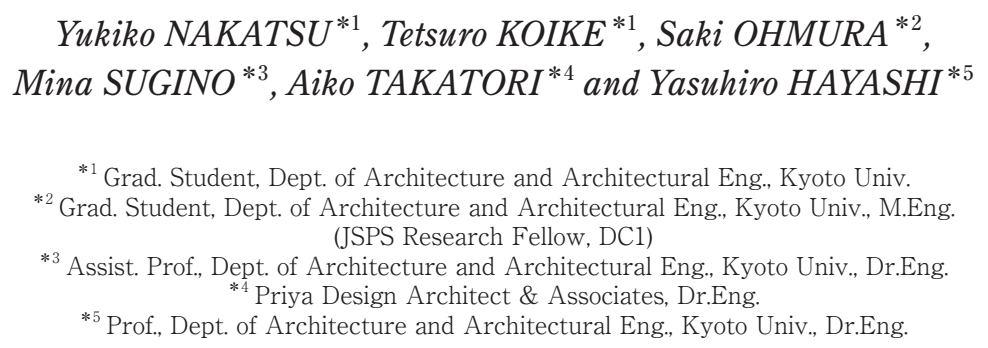

The past inland crustal earthquakes, such as the 1995 Hyogo-ken Nambu earthquake, the 2007 Nigata-ken Chuetsu-oki earthquake and the 2016 Kumamoto earthquake, destroyed many wooden structures in Japan. It is desirable to conduct appropriate seismic reinforcement in order to prevent inland crustal earthquakes occurring often in recent years from pushing down wooden buildings.

Authors have been doing research on seismic reinforcement for traditional town houses, machiya, in Kyoto ${ }^{1}$. The findings obtained from the research are as follows: machiya's joints are not strong enough to resist to horizontal member's pulling out in particular, and severe damage in a specific story caused by the unbalance of yield strength and stiffness in each story or plane structure lowers the deformability. In other words, for conducting rational seismic reinforcement, it is preferable that we can design with reinforcing elements which allow us to control elements' mechanical characteristics in accordance with features of structures.

Wooden grid wall (2)-6) and ladder-type frame ${ }^{7-9)}$ are suggested as reinforcing elements for wooden structures. In both of them, wood's embedment at joints resists seismic force. However, as well as the experiments in reference1), these reinforcing elements may be ineffective if their position or strength is improper.

Therefore, authors propose a new reinforcing element, called Amida-shaped frame, composed of columns and horizontal members. Amida-shaped frame can be controlled its strength and deformability by changing the number and the size of columns and horizontal members. By using Amida-shaped frame which has such characteristic, we aim to establish seismic reinforcement method which is applicable to various structures.

From the above, first, we conduct static loading tests of Amida-shaped frames for comprehending their mechanical characteristics. Then, we simulate the static loading tests with analysis models to confirm the mechanical characteristics which can't be identified at experiments. This paper is original in proposing that it is important to consider horizontal member's bending deformation, breakage, axial force and to say nothing of embedment when we design Amida-shaped frame.

The major findings obtained from the research are summarized as follows:

a) The maximum horizontal force of Amida-shaped frames rises in proportion to the total number of horizontal members. The particular damage is breakage of horizontal members at the columns' surface. When the horizontal member breaks, the horizontal force drops rapidly.

b) When the height of horizontal members is bigger, the rotational angle when the horizontal member breaks and the maximum horizontal force are larger. The bigger the height of horizontal members is, the less the ratio of the maximum bending moment to the flexural capacity is.

c) In case the height of horizontal members is small, we are capable of overstimulating the rigidity if we don't consider the bending deformation of horizontal members.

d) If we don't consider the axial force of horizontal members appropriately which derives from embedment at joints of columns and horizontal members, it is difficult to evaluate the bending moment distribution of columns. 